MA RASTKO LOMPAR, istraživač-pripravnik

Balkanološki institut SANU

Beograd, Republika Srbija

UDK 94(497.1)"1935/1941"(093.2)

rastko.lompar@bi.sanu.ac.rs

329.18:929 Љотић Д. В.(093.2)

originalan naučni rad / original scientific paper

primljeno / received: 27. 12. 2019.

prihvaćeno / accepted: 20. 5. 2020.

https://doi.org/10.29362/ist20veka.2020.2.lom.85-102

\title{
AFERA „TEHNIČKA UNIJA“ I VEZE JNP ZBORA SA NACISTIČKOM NEMAČKOM 1935-1941."
}

APSTRAKT: $U$ članku se, na osnovu neobjavljene građe iz nemačkih $i$ srpskih arhiva, razmatraju priroda i intenzitet veza koje je Jugoslovenski narodni pokret Zbor ostvario sa različitim organima nacističke Nemačke tokom međuratnog perioda. Poseban akcenat stavljen je na aferu ,Tehnička unija “ iz 1937. godine, kada je JNP Zbor optužen da prima finansijsku pomoć od Nemačke i da predstavlja agenturu njene obaveštajne službe.

KLJUČNE REČI: JNP Zbor, Dimitrije Ljotić, nacistička Nemačka, nemačka obaveštajna služba, Tehnička unija

Jugoslovenski narodni pokret Zbor nastao je ujedinjenjem nekoliko integralnojugoslovenskih pokreta i grupacija (Jugoslovenska akcija, Združenje borcev Jugoslavije, grupa oko Dimitrija Ljotića i lista Otadžbina, grupa oko lista Buđenje). ${ }^{1}$ Nastao na talasu nacionalne remobilizacije posle ubistva kralja Aleksandra I 1934. godine, od samog početka privukao je pažnju nemačkih diplomata u Beogradu. Izveštavajući o novoj nacionalističkoj organizaciji, nemački poslanik Viktor fon Heren zapazio je da Zbor ima sličnosti sa nacionalsocijalizmom kako u ideologiji tako i u javnim nastupima. Kao izrazito filonemačka apostrofirana je Jugoslovenska akcija i grupa oko Ratka Parežanina, direktora Balkanskog instituta. S druge strane izražena je zabrinutost zbog prisustva antinemačkih elemenata u Boju, ali je celokupno grupisanje pokreta ocenjeno pozitivno. Dometi pokreta višestruko su precenjeni, jer je fon Heren izveštavao o 400.000 pristalica. $^{2}$ Iako sam Dimitrije Ljotić nije imao, prema raspoloživim izvorima, nikakve veze sa Nemačkom i nacistima u tom trenutku,

\footnotetext{
${ }^{*}$ Rad je deo projekta Istorija političkih ideja i institucija na Balkanu u 19. i 20. veku (br. 177011), koji finansira Ministarstvo prosvete, nauke i tehnološkog razvoja Republike Srbije.

${ }^{1}$ Vidi: Младен Стефановић, Збор Димитрија Љотића (Београд: Народна књига, 1984); Mirko Bojić, Jugoslavenski narodni pokret ZBOR (Beograd: Narodna knjiga, 1999); Milutin Propadović, D. V. Ljotić i Komunistička partija Jugoslavije (Northampton: Iskra, 1990); Ратко Парежанин, Други светски рат и Димитрије В. Љотић (Београд: приватно издање, 2001).

${ }^{2}$ Istorijski arhiv Beograda (IAB), Zbirka o radu Ljotićeve organizacije Zbor (1929), k-2, Okupljanje jugoslovenskih nacionalnih saveza, 20.12. 1934.
} 
neki od članova pokreta jesu, te ovakva ocena nije neosnovana. Primera radi, Stanislav Krakov je maja 1934. nakon povratka iz Nemačke održao u Beogradu predavanje o novoj Nemačkoj, u kojem je veoma hvalio mere nacističkog režima. Ovakav angažman ne samo da je pozitivno ocenjen od strane nemačke diplomatije već je i glavni organ nacističke partije preneo delove Krakovljevog predavanja. ${ }^{3}$ Ovakav stav delila je i nemačka štampa pozitivno pišući o objedinjavanju ,fašističkih organizacija“" u Jugoslaviji. ${ }^{4}$

S druge strane, sam pokret Zbor, za razliku od brojnih radikalno desničarskih političkih partija međuratne Evrope, nije odmah tražio „vezu“ sa moćnim nacističkim režimom. Zapravo, jedan deo članstva Jugoslovenske akcije (JA), oduševljen nacizmom (grupa Kranjec-Koroman), odvojio se od pokreta nakon fuzije, smatrajući da je JA izgubila svoju „nacionalno-socijalističku“ (sic) ideologiju. ${ }^{5}$ Doista, u tekstovima samog Dimitrija Ljotića, kao i u ostaloj partijskoj štampi u periodu neposredno pre i posle osnivanja pokreta (1934-1935), preovladavala je skepsa prema nacističkoj Nemačkoj. Mladi režim u Nemačkoj je svojim žestokim zahtevima za revizijom Versajskog poretka i političkim nasiljem izazivao podozrenje te je, stoga, Ljotić pozdravio krah nacističkog puča u Beču 1934. godine. ${ }^{6}$ Istovremeno je posmatrao i ideologiju nacionalsocijalizma kritičkim očima: „Ali polazeći od neodređenog ka nejasnom, nacional-socijalizam (sic) je koristio stare puteve i metode, te se zato ne može otresti ni obzira ni obaveza, koje takvi putevi i metode nameću“". Činilo mu se na početku da je nacionalsocijalizam u osnovi nerevolucionaran pokret čija je ideologija „konglomerat“ ${ }^{8}$. Smatrao je da ipak nije sve u nacionalsocijalizmu loše, pogotovo ne njegove socijalne mere. Tako je hvalio nacističku politiku prema studentima, ali je preporučivao svojim zemljacima drugačiji put: „Ne unosimo u našu otadžbinu ni tuđ duh, ni obožavanje tuđina, jer bi to bila opasnost po onom (sic) što nam je najsvetije, opasnost po našu samostalnost!““9 Slični negativni ili neutralni tekstovi o Nemačkoj bili su prisutni i u Otadžbini. ${ }^{10}$

\footnotetext{
${ }^{3}$ Bundesarchiv Berlin-Lichterfelde (BArch), Reichspressechef der NSDAP (NS 42)/49, Karton Stanislava Krakova; „Wie sie Deutschland sahen“, Völkischer Beobachter, 24. 5. 1934.

${ }^{4}$ Arhiv Jugoslavije (AJ), fond 38, Centralni presbiro Predsedništva Ministarskog saveta Kraljevine Jugoslavije, 429-581, „Neue Partei in Jugoslawien“, W. N. Nachrichten, 6. 9. 1935; „Neue geistige Bewegungen in Südslawien“, Deutsche Allgemeine Zeitung, 5. 1. 1935; AJ, 38-353-501, „Zusammenschuß faschistischen Organisationen“, Berliner Börsen Zeitung, 28. 12. 1934; „Südslawisch-völkische Bewegung“, Münchner Neusten Nachrichten, 29. 12. 1934; Egon Heymann, „Eine völkische Bewegung der Südslawen“, Münchner Neusten Nachrichten, 21. 1. 1935.

${ }^{5}$ Oni su podsećali da je „osvajanje ulica koje su tako uspešno vršili Hitler i Musolini jedino... ispravan metod za nas“. Citirano prema: Бранислав Глигоријевић, „Политички покрети и групе с националсоцијалистичком идеологијом и њихова фузија у Љотићевом 'Збору"”, Историјски гласник, бр. 4, (1965), 55-56.

${ }^{6}$ Димитрије Љотић, „Догађаји у Европи“, Сабрана дела 1, (Београд: Задруга, 2001), 237. U daljem tekstu СД.

7 Димитрије Љотић, „Беспуће“, СД2, 228-229.

8 Димитрије Љотић, „Стара песма“, СД1, 158-159.

9 Димитрије Љотић, „Пре свега - верни себи“, СД2, 257.

${ }^{10}$ Vidi: „Поводом Хитлеровог излета“, Отаибина, 17. 6. 1934; „Догађаји у трећем Рајху“, Отаибина, 8. 7. 1934; „Догађаји у Немачкој“, Отаибина, 15. 7. 1934; „Г. Адолф Хитлер“, Отаибина, 12. 8. 1934; „Плебесцит г. Хитлера“, Отаибина, 26. 8. 1934.
} 
Inicijalna skepsa prema nacističkoj Nemačkoj postepeno je prevladavana i od 1936. godine Dimitrije Ljotić i Zbor započinju sa pronacističkim istupima. Razloga za ovakvu promenu bilo je više. Nacistički režim se pokazao snažnim, izdržao je prve probe i pokazao da je odlučan u reviziji Versajskog sporazuma. Nemačke trupe umarširale su u Rajnsku oblast 1936. godine, nakon što je Hitler trijumfovao na referendumu u Saru. Godine između sarskog referenduma i početka Drugog svetskog rata predstavljale su godine optimizma za mnoge evropske desničare. Delovalo je da je napokon stigla alternativa ,impotentnoj““ liberalnoj demokratskoj državi, da izrasta nova autoritarna država spremna da brani naciju od svih njenih neprijatelja. Duž cele Evrope polarizacija društva na levicu i desnicu sve se više povećava, što dovodi do brojnih konfrontacija sa kulminacijom u Španskom građanskom ratu. ${ }^{11} \mathrm{Ni}$ Dimitrije Ljotić nije bio imun na ,šarm“ nacionalsocijalizma i na privlačnost njegovih uspeha. Ne treba smesti sa uma da je upravo u ovom periodu došlo do snaženja njegovog antisemitizma i antikomunizma. Ubeđenost u ,jevrejsku zaveru“ i skori dolazak boljševičke revolucije pojačala je kod Dimitrija Ljotića svest o tome da je nacionalsocijalistička Nemačka ipak poželjan politički oslonac i da je nužan dobar odnos sa njom. Socijalna politika nacionalsocijalizma delovala je Ljotiću kao rešenje za propadanje porodice, morala i ,pravih“ vrednosti. On je stoga navodio da je Hitler upravo ženskim glasovima dobio izbore, jer je nemačkim ženama ,vratio muževe“. Hitler je oslobodio Nemce iz zagrljaja alkoholizma, kurtizana i pogrešnih ideja i vratio ih ,pravim“ idealima, idealima borbe za otadžbinu, porodicu i dobrobit nacije. Demografski problemi koji su mučili Nemačku su nestali. Antipod Nemačkoj pronađen je u demokratskoj Francuskoj, koja se pod vođstvom Jevrejina Bluma odala porocima i koju potresaju problemi. ${ }^{12}$

Ljotić je počeo sa davanjem veoma pohvalnih izjava o samom Adolfu Hitleru. U razgovoru sa nemačkim obaveštajcem 1936. godine Ljotić ističe da je „Hitler najpopularnije ime među seljacima u Jugoslaviji“. On navodi da je „,̌itao i slušao Hitlerove govore $i$ da ne može da veruje da ovaj čovek (Hitler $-\mathrm{R}$. L.) kaže nešto što ne veruje iskreno“. ${ }^{13}$ Već dve godine kasnije i javno je hvalio nemačkog vođu: „Hitler je kao čovek izuzetno retka pojava. Duboko misaon, i genijalan, organizator, heroj i apostol on odista fascinira svoj narod. Nema mane ni pege na njemu. "'14 Iako se Ljotić ponekad u ovom periodu kritički izražavao prema fašizmu, kao prilikom predavanja u Sarajevu 1936. godine, ${ }^{15}$ glavni tok njegovog izlaganja ostajao je veoma afirmativan. ${ }^{16}$

\footnotetext{
${ }^{11}$ Erih Hobsbaum, Doba ekstrema: istorija Kratkog dvadesetog veka (Beograd: Dereta, 2004); Enzo Traverso, Fire and Blood: The European Civil War (London: Verso, 2016).

12 Димитрије Љотић, „Жена у данашњици“, СД3, 294-300; Димитрије Љотић, „Из мога живота“", СД11, 194-197.

${ }^{13}$ IAB, 1929, k-2, Položaj u Jugoslaviji, 1-20. 4. 1936.

14 Димитрије Љотић, „Наш национализам“, СД5, 204.

${ }^{15}$ AJ, 38-353-501, Mehmed Samsarija, „Oko predavanja g. Dimitrija Ljotića u Sarajevu“, Jugoslovenski list, 27. 5. 1936.

${ }^{16}$ Vidi: „Нова Немачка“, Отацбина, 13. 8. 1936.
} 
Pronemačka kampanja Zbora nije prošla nezapaženo kod nemačkih organa. Pored informacija iz štampe, nemački obaveštajci pružili su i informacije iz ,prve ruke“ o planovima i ideologiji pokreta. Sama činjenica da se Dimitrije Ljotić sastao sa nemačkim obaveštajcem aprila 1936. ne treba se tumačiti kao direktan kontakt Ljotića i nemačke obaveštajne službe. Naime, na osnovu građe sačuvane u srpskim arhivima ne može se utvrditi identitet obaveštajca sa kojim je Ljotić razgovarao, jer je izveštaj nepotpisan. Međutim, original izveštaja, koji se čuva u Saveznom arhivu Berlin-Lihtefelde, otkriva da je u pitanju bio Rudolf fon Malcan, dopisnik najvećeg nacističkog lista, Völkischer Beobachter-a, iz Jugoslavije. ${ }^{17}$ Fon Malcan se pre sastanka sa Ljotićem i Korenićem susreo sa Vladkom Mačekom, za šta je imao, kao dopisnik najznačajnijeg nemačkog lista, potpuno legitimne razloge. U izveštaju ne postoji nikakav nagoveštaj da je Ljotić, kao uostalom ni Maček, bio svestan da razgovara sa nemačkim obaveštajcem. Ljotić je, ipak, tokom razgovora izneo niz pohvala na račun nemačkog ,vođe“" i nacističkog režima. Nemačka štiti Jugoslaviju od agresivnih namera susedne Italije i seljaci su oduševljeni Hitlerom, istakao je Ljotić. Istovremeno je naveo da je Zbor odbio italijansku finansijsku pomoć, da je u odličnim vezama sa generalštabom i ministrom vojske Ljubomirom Marićem, kao i da ne isključuje mogućnost dolaska na vlast vojnim pučem, jer je vojska duboko nezadovoljna stanjem u državi. Fon Malcan je naveo da se na skupovima Zbora stalno pominje Hitlerovo ime. ${ }^{18}$

Ovaj izveštaj predstavljao je uvod u saradnju i intenzivirane kontakte između nacističke Nemačke i Zbora, koji su započeli sredinom 1936. godine i doživeli vrhunac tokom 1937. godine, nakon čega su drastično smanjeni kao posledica afere „Tehnička unija“. Članovi Zbora počeli su neskriveno da održavaju veze sa Nemcima. Tako je Stevan Ivanić zajedno sa suprugom bio gost na skupu organizacije ,Snaga kroz radost“ juna 1937. ${ }^{19}$ On je od ranije održavao vezu sa vodećim medicinskim (rasnim) stručnjacima, prevashodno sa članovima Instituta „Robert Koh“ u Berlinu, i već tokom 1936. godine boravio je u Nemačkoj. ${ }^{20} \mathrm{Na}$ sedmi partijski kongres u Nirnbergu, 1937. godine, pozvan je Ratko Parežanin, istaknuti član pokreta. Njegovo učešće nije obrazloženo samo time što je u publikacijama Balkanskog instituta pozivao na veću privrednu saradnju između Nemačke i Jugoslavije, niti samo njegovim simpatijama za nacionalsocijalizam, već i time što bi preko njega i Zbor bio zastupljen na danu

\footnotetext{
${ }^{17}$ BArch, Persönliche Adjutantur des Führers und Reichskanzlers (NS 10)/223, Rudolf fon Malcan, Položaj u Jugoslaviji, 1-20. 4. 1936.

${ }^{18}$ IAB, 1929, k-2, Položaj u Jugoslaviji, 1-20. 4. 1936. Doista, sačuvan je niz izveštaja sa skupova Zbora na kojima je hvaljen režim u Nemačkoj, pogotovo tokom izborne kampanje 1938. godine. Vidi: Hrvatski državni arhiv (HDA), Grupa VI-Građanske stranke i društva (1353), Inv. br. 3969.

${ }^{19}$ BArch, NS 42/49, Karton Stevana Ivanića.

${ }^{20}$ Prema svedočenjima jugoslovenskih folksdojčera koji su poznavali Ivanića, on je bio pristalica nemačke rasne doktrine i zagovarao je donošenje sličnih rasnih zakona u Jugoslaviji. Detaljnije: IAB, Zapovednik policije bezbednosti i službe bezbednosti (BDS), dosije Stevana Ivanića (I1117), Izveštaj o razgovoru sa Stevanom Ivanićem, 26. 4. 1941; Pismo Valtera Albertija, 17. 6. 1943; Александар Стојановић, Идеје, политички пројекти и пракса владе Милана Недића (Београд: Институт за новију историју Србије, 2015), 63-66.
} 
partije. ${ }^{21}$ Iako su na partijskom kongresu 1935. već učestvovali pojedini članovi Zbora, ovo je prvi put da je nečiji poziv obrazložen članstvom u Zboru.

Istovremeno, nesumnjivo po instrukcijama iz Berlina, pronacistička opoziciona grupacija među jugoslovenskim folksdojčerima, takozvani „Obnovitelji“, priključila se Zboru početkom 1937. godine. Nenacistička nemačka štampa u Kraljevini Jugoslaviji izražavala je svoje čuđenje zbog saradnje ove organizacije sa „minornom“ političkom grupacijom kao što je bio Zbor. ${ }^{22}$ „Obnovitelji“, na čijem je čelu bio pančevački lekar Jakob Avender, ostali su deo Zbora sve do marta 1938. godine, kada su istupili iz pokreta kao direktna posledica skandala oko „Tehničke unije“. ${ }^{23}$ Tada su i drugi Nemci zamoljeni da istupe iz pokreta. ${ }^{24}$

Aferu „Tehnička unija“, koja je duboko uzdrmala jugoslovensku (i evropsku) javnost, pokrenuo je, jednom svojom interpelacijom, narodni poslanik Života Milanović 30. januara 1937. godine. U svom govoru on je napao Zbor da od Nemačke tajno prima novac i pozvao državne organe da reaguju da se takva infiltracija spreči. Naime, članovi Zbora bili su osnivači zagrebačkog akcionarskog udruženja Tehnička unija (u daljem tekstu TU), koje je sa nemačkim istoimenim društvom sklopilo krajem 1936. godine sporazum o klirinškoj razmeni jugoslovenskih poljoprivrednih dobara za industrijske proizvode. Ljotićev savez voćarskih zadruga bio je prvi izvoznik u Nemačku. U svom govoru Milanović je otkrio da je glavni posrednik između Zbora i Nemaca, Milan Danić, zapravo pokršteni Jevrejin i bivši komunista Alfred Dijamantštajn. ${ }^{25}$ On je takođe, sa skupštinske govornice, tvrdio da su privredni sporazumi samo paravan za zakulisno finansiranje Zbora. Taj govor, koji je već sutradan prenela Politika, izazvao je veliku pažnju jugoslovenske štampe. Glavni sekretar Zbora Velibor Jonić odgovorio je u ime pokreta već 2 . februara pobijajući sve optužbe. ${ }^{26} \mathrm{Na}$ stranicama Politike rasplamsala se tokom februara veoma oštra rasprava između Milanovića i Jonića, koja je prenošena u ostalim listovima. ${ }^{27}$ Doista, narednih meseci Zbor je

${ }^{21}$ Politisches Archiv des Auswärtiges Amtes (PA AA), Referat D/Abteilung Inland (RZ 214), R 98692, Lista jugoslovenskih ličnosti pozvanih na partijski kongres 1937, 7. 7. 1937.

22 „Die erneuerten Erneuerer“, Deutsche Presse, 21. 2. 1937.

${ }^{23}$ PA AA, Politische Abteilung (RZ 211), R 103374, Zabeleška o Zboru, 12. 10. 1938; Zoran Janjetović, Deca careva, pastorčad kraljeva. Nacionalne manjine u Jugoslaviji (Beograd: Institut za noviju istoriju Srbije, 2005), 201; Petar Kačavenda, Nemci u Jugoslaviji 1918-1945 (Beograd: Institut za savremenu istoriju, 1991), 18-19; Dušan Biber, Nacizem in Nemci v Jugoslaviji (Ljubljana: Cankarjeva založba, 1966).

${ }^{24}$ Светомир Пауновић, Сећања сведока једног времена (Београд: С. Р. Пауновић, 2004), 155.

${ }^{25}$ Ličnost Danića/Dijamantštajna izazvala je veliku pažnju zbog činjenice da se jedan Jevrejin povezao sa samim vrhom nacističkog režima. Vidi: IAB, 1929, k-7, S. N. K, „Opasnost fašizma“, Narodno kolo, 25. 2. 1937; „Ljotićevsko-žido-masonska afera“, Hrvatska straža, 19. 2. 1937; „Alfred Diamanstein - nationalsozialistischer Führer auf dem Balkan“, Der Österreicher, 5. 3. 1937.

${ }^{26}$ Велибор Јонић, „Да ли 'Збор' г. Љотића прима помоћ од Немачке?“, Политика, 2. 2. 1937.

${ }^{27}$ Najvažniji članci Živote Milanovića: Живота Милановић, „Да ли 'Збор' г. Љотића прима у сврху агитације помоћ из иностранства?“, Политика, 4. 2. 1937; „Позадина афере Дијаманштајн Техничка унија - Збор“, Политика, 19. 2. 1937; „Народни посланик г. Живота Милановић тврди да је 'Збор' г. Љотића дисквалификован за јавни живот“, Време, 23. 2. 1937; „У свом 
bio pod udarom kao „nemačka peta kolona“ od strane ideološki najrazličitijih grupacija. Pored komunista i levičarske štampe Zbor su napadali listovi HSS-a, JRZ-a i drugih stranaka ${ }^{28}$ Rasprava u listovima imala je neretko i sudski epilog. Zbor je dobio tužbe protiv Vremena i Politike, dok je tužba protiv Većeslava Vildera nakon kontratužbe sporazumno povučena. ${ }^{29} \mathrm{U}$ većini članaka ponavljane su optužbe izrečene tokom polemike Milanović-Jonić. Izuzetak predstavlja članak iz Severne straže, napisan sredinom februara i potpisan inicijalima S. Z., u kojem se Ljotić optužuje za cepanje zadružnog pokreta i niz finansijskih malverzacija prilikom vođenja svog zadružnog saveza. Ovim člankom Ljotić se prvi put napada ne samo kao predvodnik jedne fašističke stranke već i kao vođa privredne, odnosno zadružne organizacije. ${ }^{30}$

Afera je izazvala interesovanje i međunarodne, uglavnom antifašističke, javnosti. Britanski poslanik izveštavao je svoje ministarstvo o aferi prenoseći svoje uverenje da je pisanje štampe ispravno $i$ da je Zbor plaćan iz Nemačke. ${ }^{31}$ Velikih odjeka bilo je pogotovo u francuskoj ${ }^{32}$ i čehoslovačkoj štampi ${ }^{33}$ ali i u štampi drugih zemalja. Radio Moskva i Radio Strazbur emitovali su posebne emisije posvećene ovoj aferi. ${ }^{34}$ Afera je prikazana i u nekolicini knjiga o nemačkoj ekspanziji čiji su autori bili antifašistički nastrojeni. Svojim značajem izdvajaju se knjige Ibera Bev-Merija i Norberta Mihlena, jer su obe donele izvesne nove informacije, koje se ne mogu pronaći u jugoslovenskoj štampi. Naime, Bev-Meri smešta TU u kontekst nemačkog napredovanja u Mađarskoj, Jugoslaviji, Grčkoj, Turskoj, Egiptu i Persiji. Zbor je, prema njemu, preko TU bio finansiran da bi se

одговору 'Збору' народни посланик г. Живота Милановић истиче да су у открићима у вези са 'Техничком унијом' доказане његове тврдње о везама 'Збора' са иностранством“', Политика, 26. 2. 1937. Za zboraško viđenje afere vidi: „Zašto nas kleveću?“, Vihor, 20. 2. 1937; „Друг Љотић о Техничкој унији“, Отацбина, 27. 2. 1937; „Kleveta i nasilja“, Vihor, 8. 3. 1937; „Klevetnicima“, Zbor, 15. 3. 1937; Lj., „I 'Politika' tera politiku“, Vihor, 20. 3. 1937; С. Игњатовић, „Нова изјава г. Љотића о афери“, Правда, 24. 3. 1937. Državni organi zabranjivali su zboraške letke i brošure u kojima se brane od optužbi. Vidi: HDA, 1353, Inv. br. 3969.

${ }^{28}$ Kuburić, „Karijera jednog provokatora“, Proleter, 5. 5. 1937; IAB, 1929, k-7, S. N. K, „Opasnost fašizma“, Narodno kolo, 25. 2. 1937; Димитрије Љотић, „Случај г. Адама Прибићевића“, СД9, 173; IAB, 1929, k-7, Jugoslavenski narodni pokret Zbor i Hrvati.

${ }^{29}$ M. Bojić, $n$. d., 116; „Vreme je osuđeno radi klevete Zbora!“, Vihor, 6. 5. 1937; „Да се не заборави“, Самоуправа, 27. 10. 1937.

${ }^{30}$ C. 3., „Истина о задружном и политичком раду Димитрија Љотића“, Северна стража, 18. 2. 1937.

31 Živko Avramovski, Britanci o Kraljevini Jugoslaviji, knj. 2 (Beograd/Zagreb: Arhiv Jugoslavije/Globus, 1986), 469.

32 „Yougoslavie“, Le Temps, 2. 3. 1937; „Manifestation d' antifascistes a Belgrade“, Le Treveil, 2. 3. 1937; „Manifestation antifasciste a Belgrade contre un agent hitlerien“, Le Populaire, 1. 3. 1937.

${ }^{33}$ AJ, 38-353-501, „Technische Union chce stavet most pres Dunaj“, Narodni Osvobozeni, 7. 3. 1937; „Zakaz fašističke mladeže v Jugoslavii“, Ruдe Pravo, 5. 3. 1937; „Protifašisticke demonstrace v Belehrade“, Narodni Osvobozeni, 2. 3. 1937; „Demonstrace v Belehrade pro aferu Technische Union“, Boudelnik Narodnich Listy, 1. 3. 1937; „Protifašisticke boure v Jugoslavii“, Rondelni Ranni Noviny, 1. 3. 1937; „Odhaleni rozsahle haknkrajclerske propagandy v Jugoslavii“, Nova doba, 27. 2. 1937; „Afera Technische Union“, Hospodar Rozhled, 4. 3. 1937.

${ }^{34}$ PA AA, RZ 211, R 103374, Informacije o emisijama radija Strazbur, 20: 45, bez datuma; Zabeleška o emisijama radija Moskve, 9. 3. 1937. 
nemački politički uticaj u Jugoslaviji pojačao. Novinu predstavlja tvrdnja da je Dijamanštajn preko svojih kontakata sa nacistima, nameravao da „učini uslugu nemačkim Jevrejima, koji su izbegli u Jugoslaviju, pomažući ih da deblokiraju svoja potraživanja zadržana u Nemačkoj"“. ${ }^{35}$ S druge strane, Mihlen je izneo tvrdnju da je Nemačka finansirala Zbor tako što je prekomerno plaćala kilogram šljiva koje je izvozio Ljotićev savez zadruga. ${ }^{36}$ Pošto je razmena bila klirinška, tako je de facto Jugoslavija plaćala propagandu protiv same sebe. ${ }^{37}$

U celini posmatrano, tokom kampanje protiv Zbora došlo je do zbližavanja tri različite političko-ideološke grupacije, koje su za napade na pokret imale sopstvene motivacije i ciljeve. U pitanju su pristalice JRZ, KPJ i demokratski nastrojeni anglo/frankofilni krugovi. Članovi i simpatizeri JRZ, iz čijih redova je afera i lansirana, svoju kritiku ograničavali su na Zbor, pazeći da ne istupaju protiv nacističke Nemačke i ekonomske saradnje sa njom, koja je apostrofirana kao poželjna. S druge strane, komunisti ne samo da su kritikovali Zbor i Nemačku već su u aferi videli opštu fašizaciju jugoslovenskog društva. ${ }^{38}$ Napokon, demokratski orijentisani listovi i političke opcije videli su u TU manifestaciju agresivne nemačke spoljne politike na Balkanu. Iako su pokrenuli aferu, Stojadinović i njegovi sledbenici ubrzo su izgubili kontrolu nad narativom oko nje, koji je sve više počeo da dobija jasne antinemačke i antinacističke tonove, pogotovo u međunarodnim odjecima. Samim tim, već od februara 1937. primetna su nastojanja pojedinih režimskih listova, prevashodno glasova krupnog zagrebačkog kapitala, da ublaže značaj afere. U tim tekstovima isticano je da je značaj TU višestruko uveličan i da nije nikakvu štetu donela Jugoslaviji, ali da ovakva „suvišna“ politizacija samo šteti jugoslovensko-nemačkim ekonomskim odnosima. ${ }^{39}$

Nažalost, ova afera do danas nije na adekvatan način istražena, i izlaganje se praktično isključivo bazira na polemici u štampi. U socijalističkoj istoriografiji na istoriografsku sliku o TU uticala je Uprava državne bezbednosti. Najznačajnija studija o Zboru napisana tokom ovog perioda iz pera Mladena Stefanovića svoje izlaganje o aferi u potpunosti bazira na elaboratu trećeg odeljenja UDB-e o nemačkoj obaveštajnoj službi. ${ }^{40}$ I u ravnogorskoj emigrantskoj publi-

${ }^{35}$ Х. Бев-Мери, К највећој Немачкој (Загреб: б. и., б. г.), 40-42. Knjiga je objavljena u originalu na francuskom: Hubert Beuvre-Mery, Vers la plus grande Allemagne (Paris: Hartmann, 1939). Vidi Ljotićev odgovor na ovu knjigu: Димитрије Љотић, „Иш, не праши!“, СД8, 267-268.

${ }^{36}$ Prema Mihlenu, Nemačka je plaćala kilogram šljiva 2,3 dinara, dok je realna cena bila 1,4 dinara po kilogramu. Ovu tezu preuzeo je Džejkob Hoptner u svojoj studiji. Vidi: Jacob Hoptner, Jugoslavija u krizi 1934-1941 (Rijeka: Otokar Keršovani, 1972), 130.

${ }^{37}$ Norbert Mühlen, Der Zauberer. Leben und Anleihen des dr. Hjalmar Horace Greeley Schacht (Zürrich: Europa Verlag, 1938), 136-138.

${ }^{38}$ Iz samog Zbora tvrđeno je da ova afera nije ništa drugo do rezultat nastojanja komunista да diskredituju slične pokrete u celoj Evropi. Vidi: „Међународна комунистичка завера“, Отаибина, 20. 3. 1937.

${ }^{39}$ I. M, „Povodom jedne kampanje“, Jugoslovenski Lloyd, 20. 2. 1937; x-x; ,Jedna suvišna afera“, Jugosloven, 6. 3. 1937.

${ }^{40}$ Stefanović se u svom izlaganju o aferi poziva na knjigu publicista Slavka Odića i Slavka Komarice, Noć i magla: Gestapo u Jugoslaviji (Zagreb: Centar za informacije i publicitet, 1977), 
cistici preovladavalo je mišljenje da je Zbor bio u službi nemačke obaveštajne službe, dok je zboraška publicistika i istoriografija poricala bilo kakve finansijske malverzacije. ${ }^{41}$ Afera je i dalje u velikoj meri neistražena, pogotovo u svetlu činjenice da nijedan od radova nije konsultovao originalnu nemačku građu. ${ }^{42}$

Prvi kontakti između nemačkih organa i Ljotića događaju se upravo aprila 1936, kada je i razgovarao sa već pominjanim Malcanom. Tada u Jugoslaviju dolazi Milan Danić, ${ }^{43}$ koji se pod u potpunosti nerazjašnjenim okolnostima nametnuo u Nemačkoj kao čovek od poverenja. On je bio delegiran od strane dve nemačke institucije, privrednog odeljenja Spoljnopolitičke službe nacističke stranke (Wirtschaftsabteilung des Ausenpolitischen Amtes der NSDAP, u daljem tekstu APA) i Službe za ishranu Rajha (Reichsnährstand, u daljem tekstu RNST). Njegovi neposredni rukovodioci bili su Valter Maletke (Walter Malletke iz APA) i Ber (Beer iz RNST). ${ }^{44}$ Nakon što je uspostavio kontakt sa Ljotićem, on je priznat od obe strane za posrednika u budućim privrednim pregovorima, pri čemu je Ljotić naglasio da on ,ima samo u ovim okvirima punomoćje ${ }^{\text {“4 }}{ }^{45}$ Danić je narednih neko-

koja je zapravo samo skraćena verzija elaborata UDB-e. Vidi: Nemačka obaveštajna služba, knj. II (Beograd: UDB, III odeljenje, 1955).

${ }^{41}$ Предраг Ивановић, Ко су љотићевичи? (Крагујевац: Погледи, 2014), 38. Za zboraški pogled vidi: M. Propadović, $n$. d., 197-224; M. Bojić, $n$. d., 110-117.

${ }^{4}$ Po svemu sudeći, najprecizniji pregled afere nalazi se u: Милан Кољанин, Јевреји и антисемитизам у Краљевини Југославији 1918-1941 (Београд: Институт за савремену историју, 2008), 279-281.

${ }^{43}$ Alfred Dijamantštajn (Milan Danić) rođen je 1896. godine u Osijeku. Kao mladić je bio problematičnog ponašanja i učestvovao je u antisrpskim demonstracijama u Zagrebu 1914. Tokom vremena revolucija 1919. godine živeo je u Mađarskoj i postao delegat Bele Kuna zbog znanja srpskog jezika. Pod konspirativnim imenom „Nenad“ prešao je u Jugoslaviju. Stigao je u Zagreb, gde je radio na podizanju oružane pobune protiv Kraljevine SHS, povezavši se ne samo sa zagrebačkom ćelijom KPJ već i sa hrvatskim separatistima. Prema kasnijim svedočanstvima nije bio omiljen kod zagrebačkih komunista jer „samo lumpuje“, a i sumnjičen je, iako neosnovano, da je bio policijski provokator. Uhapšen je i osuđen na zatvor u prvom velikom antikomunističkom procesu 1920. godine. Potom mu se trag gubi sve do afere „Tehnička unija“, kada se pojavljuje u Berlinu pod imenom Milan Danić. Tokom Drugog svetskog rata uhapšen je i streljan od Nemaca 1941. ili 1942. godine. Detaljnije o Alfredu Dijamanštajnu: Toma Milenković, „Vladimir Ćopić u jugoslovenskom radničkom pokretu“, u: Vladimir Ćopić: život i djelo (Rijeka: CHRP, 1978), 110-113; Zorica Stipetić, Argumenti za revoluciju - August Cesarec (Zagreb: CDC, 1982), 110-113; Коста Николић, Бољшевизаиија КПЈ 1919-1929 (Београд: Институт за савремену историју, 1994), 38-40; Toma Milenković, „Nekoliko dokumenata o delatnosti Jugoslovenskih internacionalista u Mađarskoj Sovjetskoj Republici“, Prilozi za istoriju socijalizma, br. 6 (1969), 342; Vujica Kovačev, Na zajedničkom frontu revolucije (Beograd: Institut za savremenu istoriju, 1987), 140; М. Кољанин, Јевреји и антисемитизам у Краљевини Југославији 1918-1941, 281; Nemačka obaveštajna služba, knj. 4 (Beograd: Uprava državne bezbednosti, III odeljenje, 1959), 772.

${ }^{44}$ U elaboratu UDB-e i pojedinim tekstovima u štampi službenik APA Arno Šikedanc (Arno Schickedanz), takođe se dovodi u vezu sa ovim pregovorima, ali se njegovo ime ne nalazi u građi koju smo koristili.

45 BArch, Kanzlei des Führers der NSDAP, Dienststelle Bouhler, (NS 51)/5, Valter Maletke, Zabeleška o Jugoslaviji, 17. 8. 1936. 
liko meseci (april-avgust) proveo u Jugoslaviji vodeći razgovore o privrednoj saradnji sa nizom stručnjaka i preduzeća. ${ }^{46}$ On je juna 1936. takođe vodio i razgovore sa državnim organima obavestivši ih o svom radu. Putovao je u Smederevo, Beograd, Zagreb, posebno se povezavši sa nekolicinom zagrebačkih stručnjaka (zboraši inženjeri Marko Jurinčić i Marsel Srkulj), koji će činiti jezgro budućeg akcionarskog društva TU u ovom gradu. Njemu nisu date odrešene ruke za rad u Jugoslaviji, već su ubrzo u Beograd stigli službenici fon Bruk (von Bruck iz APA) i Ber (RNST) da ga nadgledaju. Tokom jula 1936. fon Bruk je upoznao Danića sa izvesnim profesorom Endruksom (Endrucks), koji je bio čovek od poverenja gaulajtera istočne Pruske, Eriha Koha (Erich Koch). Danić i Endruks su se ubrzo sporazumeli da iz budućih pregovora o stvaranju TU isključe APA i RNST. Maletke je pokušao to da spreči, ali je nakon telefonskog razgovora sa gaulajterom Kohom, koji se pozvao lično na rajhsmaršala Geringa, bio prisiljen na povlačenja iz pregovora. Od avgusta 1936. dalji pregovori između Ljotića i nemačkih organa čvrsto su bili u rukama gaulajtera Koha, odnosno Hermana Geringa. ${ }^{47}$

Danić je nastavio rad na stvaranju jednog akcionarskog društva u Jugoslaviji, koje bi sa istoimenim nemačkim društvom, koje je organizovao Endruks, na klirinškoj osnovi vršilo razmenu jugoslovenskih poljoprivrednih dobara za nemačke industrijske proizvode. ${ }^{48}$ Nemačka TU nije bila formirana samo zbog saradnje sa Jugoslavijom, već su istovremeno tekli pregovori i sa pojedincima iz drugih država. Sadržajni kontakti, iako i dalje ne na nivou veza sa Zborom, bili su ostvareni sa predstavnicima iz Kine i Turske. ${ }^{49}$ Uspešna razmena poslužila bi kao odskočna daska za buduću intenzivniju jugoslovensko-nemačku privrednu saradnju. Prvi test buduće saradnje bio je izvoz 300 vagona šljiva iz Jugoslavije, koje je trebalo da isporuče Ljotićeve zadruge. Erih Koh je izražavao zadovoljstvo saradnjom, istovremeno se žaleći na nedovoljnu kooperativnost određenih nemačkih (donekle i jugoslovenskih) državnih organa. U izvorima nema potvrde za Mihlenovu tvrdnju da je nemačka strana svesno kupovala šljive po previsokoj ceni. Pomalo paradoksalno, nemački organi zahtevali su od Danića/Dijamantštajna da proveri da li je vođstvo Ljotićevih zadruga u rukama dvojice jugoslovenskih Jevreja (Mandela i Rozenkrojca). ${ }^{50}$ Uprkos izvesnim problemima, pregovori oko isporuke šljiva su uspešno završeni. Nakon što je Koh posetio Jugoslaviju, bio je veoma optimističan u pogledu saradnje sa Jugoslavi-

${ }^{46}$ Danić je bio zainteresovan za saradnju ne samo sa Ljotićevim savezom proizvođača šećerne repe i voća već i sa proizvođačima energije (Elektrizitätslinie Wasserwerk Kuljić) i fabrikama konoplje (Hanffabrik Godomin). Takođe je predlagao saradnju u budućoj elektrifikaciji zemlje i železničke linije Dunav-Jadran. Detaljnije: BArch, Deutsche Revisions - und Treuhand AG (R 8135)/1651, Izveštaj nemačkog revizorskog društva o akcionarskom društvu Tehnička unija, Berlin, 25. 5. 1937.

${ }^{47}$ BArch, NS 51/5, Valter Maletke, Zabeleška o Jugoslaviji, 17. 8. 1936. Erih Koh je bio u sukobu sa brojnim nacističkim funkcionerima, prevashodno sa Hajnrihom Himlerom, dok je njegov zaštitnik bio Herman Gering.

${ }^{48}$ Prema revizorskom izveštaju, tokom rada na organizaciji ,jugoslovenske grupe“ Danić je potrošio 14.000 rajhsmaraka, odnosno oko 250.000 dinara.

${ }^{49}$ BArch, R 8135/1651, Izveštaj nemačkog revizorskog društva o akcionarskom društvu Tehnička unija, Berlin, 25. 5. 1937.

${ }^{50}$ BArch, NS 51/5, Razgovor sa Grosom, odeljenje hortikulture, 18. 8. 1936. 
jom, ali i svestan izvesnih poteškoća. Naime, tokom pregovora dogovorena je godišnja razmena u visini od 100 miliona maraka. Ljotićev zadružni pokret bio je suviše mali da bi mogao da obezbedi ovakvu, za jugoslovenske uslove veoma veliku, količinu proizvoda. Stoga je bilo potrebno da se saradnja proširi gotovo na ceo zadružni pokret u Jugoslaviji, što je za sobom povlačilo da Zbor gubi ekskluzivnost. Iako Koh nije imao sumnje oko toga da li je ovakva saradnja korisna za nemačku stranu, smatrao je da rezultat može biti suprotan od planiranog, odnosno da može doći do slabljenja ugleda i snage Zbora. ${ }^{51}$ Tok pregovora ukazao je na to da je Zbor, iako ideološki blizak pokret i samim tim poželjan partner, nedovoljno snažan da sam iznese ambiciozno postavljene ciljeve TU.

Berlinska i zagrebačka TU formirane su krajem 1936, nakon čega su predstavnici dvaju udruženja započeli zvanične pregovore o saradnji. ${ }^{52}$ Postignut je dogovor prema kojem su TU privatna akcionarska društva, koja se zalažu za ,,mirni promet između naroda" ne dirajući u postojeće trgovinske ugovore između Nemačke i Jugoslavije (članovi 1 i 2). Oba partnera se obavezuju na princip ravnopravnosti u međusobnim odnosima, te ne postoji mešovita uprava, jer nijedno od društava „,ne može biti kod drugoga niti direktni, niti indirektni sudeonik“ (član 3). Za donošenje zajedničkih odluka nadležan je unijski savet, koji sačinjava isti broj članova oba upravna odbora, a koji se sastaje jednom u dva meseca, naizmenično u Nemačkoj i Jugoslaviji (član 12). ${ }^{53}$ Ciljevi nisu obuhvatali zamenu jugoslovenskih (voće, kukuruz, stočna hrana, uljarice, životinjske masti, konoplja) za nemačke (tehnička pomagala i zadružne instalacije) proizvode, već i širu saradnju u oblasti saobraćaja, rudarstva, elektrifikacije i dr. (član 4), o čemu je Danić već ranije pregovarao. ${ }^{54}$ Saradnja je predviđena za narednih deset godina, a podeljena na dva subperioda od po pet godina, dok je budžet bio predviđen na 270 miliona švajcarskih franaka (član 5). Ugovor o uniji potpisan je u decembru 1936. godine.

Ambiciozno zamišljena saradnja nije mogla ni da bude uspešno otpočeta zbog izbijanja afere mesec dana kasnije. Dok je još polemika JonićMilanović trajala u štampi, Ljotić se počeo distancirati od TU, navodeći da je on od dalje saradnje odustao još decembra 1936. godine, o čemu nema podataka u izvorima. ${ }^{55}$ Po svemu sudeći, Dimitrije Ljotić je vrlo brzo shvatio razmere skandala i njegove političke posledice, te je započeo sa isključivanjem iz pokreta onih članova koji su bili previše eksponirani u TU. ${ }^{56}$ Međutim, samo udruže-

\footnotetext{
${ }^{51}$ BArch, NS 51/5, Zabeleška o razgovoru sa gaulajterom Kohom, 18. 8. 1936.

${ }^{52}$ Berlinska TU formirana je 16. oktobra, dok je zagrebačka potvrđena od odeljenja za trgovinu Banske uprave Savske banovine 30. decembra. AJ, fond 65, Ministarstvo trgovine i industrije Kraljevine Jugoslavije, fascikla 1484, Odluka, 30. 12. 1936. U istoj kutiji nalaze se i osnivački dokumenti jugoslovenske TU.

${ }^{53}$ AJ, fond 115, Zbor Dimitrija Ljotića, Nacrt za ugovor o uniji.

${ }^{54}$ Isto. Uporedi sa fusnotom 46.

${ }^{55}$ Ime Dimitrija Ljotića ne nalazi se, doduše, među 11 potpisnika osnivačkih akata jugoslovenske TU. Vidi: AJ-65-1484, Pravila; Utemeljiteljna osnova.

${ }^{56} \mathrm{IAB}$, Bezbednosno-informativna agencija (BIA), dosije Velibora Jonića, Zapisnik sa saslušanja Velibora Jonića; Миодраг Зечевић, Документа са суђења равногорском покрету, књ. 1 (Београд: СУБНОР, 2001), 1072-1073.
} 
nje u Zagrebu davalo je izjave da neće odustati od dogovorenih ciljeva i da neće obustaviti rad, ali je učinjena šteta bila prevelika. Zbog pritisaka društvo je jula 1937. preimenovano u „Organizaciono i privredno a. d.“, a potom tiho izbrisano iz trgovačkog spiska naredne godine. ${ }^{57}$ Ista sudbina zadesila je i nemačku TU. Fijasko u pregovorima sa Jugoslavijom obesmislio je saradnju sa predstavnicima iz Turske $\mathrm{i}$ Kine, te je i berlinsko društvo likvidirano maja 1937. godine. ${ }^{58}$

Nameće se ključno pitanje: Kakva je pozadina ove afere? Života Milanović zasigurno nije bio njen inicijator, već izvršilac. On se već aprila 1938. nalazio u središtu nove korupcionaške afere, doduše mnogo manjeg značaja, kada je optuživao dvojicu osiječkih funkcionera za finansijske malverzacije. ${ }^{59}$ Praktično, nakon njegove polemike u štampi on nestaje iz izvora. Prema podacima UDB-e, ključ afere ležao je u frakcijskim borbama u nacističkoj Nemačkoj. Naime, službenici APA, koji su bili nezadovoljni zbog činjenice da su Endruks i Koh preuzeli organizaciju TU, predali su kompromitujući materijal o aferi i samom Daniću vođi APA, Rozenbergu. Taj materijal pokušao je Rozenberg da iskoristi protiv Koha, ali ga je Gering preduhitrio predavši Milanu Stojadinoviću redigovan materijal, iz kojeg je ,izbacio sve ono što se odnosilo na pozadinu afere $\mathrm{i}$ odnose nacističkih vođa $\mathrm{u}$ Trećem Rajhu“. ${ }^{60}$ Stojadinović je potom iskoristio ovaj ,poklon“ da bi se obračunao sa Dimitrijem Ljotićem i njegovim pokretom.

Iako donekle oslonjeno na proverljive podatke, ovakvo objašnjenje afere je prema našem mišljenju pogrešno. Doista, sukob između Maletkea i Koha odigrao se nakon što je Endruks preuzeo vođenje daljih pregovora sa Danićem jula 1936. godine. Maletke je, prema svom priznanju, nazvao Danića i rekao mu da ne sarađuje sa Endruksom, jer je on ,fantasta“ koji ne zna ništa o političkim okolnostima. Međutim, istog dana mu je gaulajter Koh zapretio, ${ }^{61}$ te je on bio prinuđen da ponovo pozove Danića i da se izvini zbog napada na Endruksa, koji je jedini postao nadležan za pregovore. Maletke je u svom objašnjenju naveo da je to uradio da se „u inostranstvu ne bi saznalo da ima sukoba unutar partijskih organa“. Samim tim, jasno je da nemački organi nisu priželjkivali skandal. Takođe, ne deluje mnogo verovatna ni hipoteza da je Gering dostavio dokumenta Stojadinoviću, kada dokumenta nedvosmisleno otkrivaju da je Koh radio upravo po Geringovim naređenjima, te da on nije imao razloga da sabotira njegove napore. ${ }^{62}$

Koliko je Nemačka pretrpela na propagandnom polju najbolje svedoče dokumenta Ministarstva inostranih poslova koje je bilo potpuno neupućeno u tok pregovora. Međutim, kada je afera izbila, poslanik fon Heren je svakodnevno

\footnotetext{
${ }^{57}$ AJ, 65-1484, Promjena pravila, 7. 7. 1937; Х. Бев-Мери, н. д., 42.

${ }^{58}$ BArch, R 8135/1651, Izveštaj nemačkog revizorskog društva o akcionarskom društvu Tehnička unija, Berlin, 25. 5. 1937.

${ }^{59}$ Vidi: Života Milanović, Koga su najmili da ih brani? (B. m: b. i, 1938).

${ }^{60}$ М. Стефановић, н. д., 68-69.

61 „Čujete li, Maletke, znate vi dobro šta se dogodi onome ko me ometa“, rekao je Koh Maletkeu tokom telefonskog razgovora. BArch, NS 51/5, Valter Maletke, Zabeleška o Jugoslaviji, 17. 8. 1936.

${ }^{62}$ BArch, NS 51/5, Zabeleška o razgovoru sa gaulajterom Kohom, 18. 8. 1936.
} 
izveštavao Berlin o novim optužbama na račun Nemačke i Zbora. ${ }^{63}$ On je takođe zahtevao da ministarstvo energično insistira na tome da se ostali organi više ne mešaju u aferu. Ministarstvo inostranih poslova je još ranije uputilo upozorenje Ministarstvu propagande da se uzdrži od komentarisanja dešavanja u Jugoslaviji, ocenivši svako dalje mešanje Nemačke štetnim. ${ }^{64}$ Fon Heren je podvlačio da je ova afera odlična demonstracija opasnosti koja preti ukoliko se nemački organi povezuju sa lokalnim političkim akterima bez znanja poslanstva, koje je najupućenije u problematiku. On je isticao kako su ovu aferu iskoristili antinemački elementi u Jugoslaviji, poput „,komunističke“ Politike, da podstaknu „hajku“ na Nemačku i da zakomplikuju odnose sa njom. Primetio je, takođe, da poslanstva Francuske i Čehoslovačke u Jugoslaviji vešto koriste situaciju. ${ }^{65}$

Jugoslovenski organi su istovremeno vršili pritisak na Nemačku da se distancira od Ljotića i Zbora, uslovljavajući dalju saradnju. Milan Stojadinović je u razgovoru sa Rudolfom fon Malcanom rekao da mešanje Nemačke u unutrašnju politiku Jugoslavije ugrožava dobre odnose među dvema zemljama. Malcan je preneo svoje uverenje da $\mathrm{u}$,krugovima vlade veruje svako u novčanu podršku [Zboru - R. L.] s naše strane ${ }^{c .}{ }^{66}$ Kao dodatni problem on je apostrofirao ponašanje pokreta Obnovitelja, koji su počeli sve više da se pojavljuju na javnim nastupima Zbora ${ }^{67} \mathrm{~S}$ obzirom na to da je vlada spremna ,oštrim policijskim merama“ da deluje protiv Zbora, on je savetovao da se Nemačka u potpunosti distancira od TU, kao i da se Obnovitelji upozore na štetnost njihove saradnje sa Zborom. ${ }^{68}$ Marta 1937. godine JNP Zbor je zbog izazivanja nasilja, kao i zbog navodnog primanja finansijske pomoći od strane države, stavljen pod policijsku prismotru i vlastima je sugerisano da se njihovi skupovi unapred zabranjuju.$^{69} \mathrm{U}$ Berlinu je na likvidaciji afere radio, iako nezvanično, dopisnik Centralnog Presbiroa Miloš Crnjanski. On je već 21. februara posetio Ministarstvo inostranih poslova i upozorio na opasnu antinemačku propagandu u Jugoslaviji, koju prema njegovom mišljenju vode „narodno frontovski krugovi i francusko poslanstvo“. Sugerisao je da se nemački organi obrate odgovornim mestima u Beogradu kako bi se afera okončala bez dalje štete po jugoslovensko-nemačke odnose. ${ }^{70}$ Crnjanski je nekoliko meseci kasnije prilikom susreta sa Rozenbergom kritikovao Dimitrija Ljotića i njegov pokret. O tome je obavestio Milana Stojadinovića napisavši: „Ja sam g.

\footnotetext{
${ }^{63}$ Heren je uputio šest izveštaja tokom februara 1937. u kojima je detaljno prenosio novinske tekstove o TU. Istovremeno je o aferi, sa sličnim zaključcima, izveštavao Rudolf fon Malcan. Vidi: PA AA, RZ 211, R103374; BArch, NS 51/5.

${ }^{64}$ PA AA, RZ 211, R103374, Ministarstvo inostranih dela-Ministarstvu propagande, 17. 2. 1937.

${ }^{65}$ PA AA, RZ 211, R103374, Viktor fon Heren, Izveštaj o medijskoj kampanji protiv TU, 19. 2.1937.

${ }^{66}$ BArch, NS 51/5, Rudolf fon Malcan, Izveštaj, 11. 2. 1937.

${ }^{67} \mathrm{U}$ masovnoj tuči koja je izbila kada su komunisti pokušali da prekinu tribinu Zbora u beogradskom bioskopu Triglav, na kojoj je Ljotić nastojao da pokret rehabilituje od optužbi za petokolonaštvo, učestvovali su i Obnovitelji. Komunistički napad na Zbor, po svemu sudeći, bio je prećutno odobren od žandarmerije. IAB, 1929, k-7, Istina o zboru kod „Triglava“, 28. 4. 1937; Slavko Ćuruvija, Ibeovac ja, Vlado Dapčević (Beograd: Filip Višnjić, 1990), 40-44.

${ }^{68}$ BArch, NS 51/5, Rudolf fon Malcan, Izveštaj, 24. 2. 1937; Izveštaj, 4. 3. 1937.

${ }^{69}$ HDA, 1353, Inv. br. 3969, Okružnica Kraljevske banske uprave Savske banovine, 4. 3. 1937.

${ }^{70}$ PA AA, RZ 211, R103374, Zabeleška o razgovoru sa jugoslovenskim atašeom za štampu, 21. 2. 1937.
} 
Rozenbergu, u Nirnbergu, rekao šta mislim o našim fašistima i vođi fašista. On ima sasvim maglovite pojmove o ulozi g. Ljotića. ${ }^{\text {(71 }}$

Prema našem mišljenju aferu su pokrenuli Milan Stojadinović i njegovi saveznici, pogotovo Vojislav Đorđević, koji je bio izložen velikim napadima Dimitrija Ljotića zbog svog vođenja Glavnog saveza zemljoradničkih zadruga. Ljotić, koji je još 1934. godine izbačen iz saveza i koji je godinama vodio kampanju protiv Đorđevića, smatrajući ga korupcionašem i ,grobarom“ zadrugarstva, tokom 1936. žestoko se zamerio ne samo Glavnom savezu već i krupnom kartelu prerađivača šećera. Pokušao je da izgradi sopstvenu fabriku za preradu šećera u Smederevu, a kada je ta akcija propala, usled ometanja od strane državnih organa, inicirao je proteste zadrugara ispred Vlade januara 1937. godine. ${ }^{72}$ Takođe, kontaktima sa Nemcima i dogovorenom saradnjom, koja bi u svakom slučaju dovela do porasta ugleda i finansijske moći pokreta, uznemirio je čelne ljude Stojadinovićevog režima. Uz to, upravo 1937. godine dolazi do obračuna autoritarnih režima u Mađarskoj i Rumuniji sa fašističkom opozicijom, koja je u svim zemljama bila oslonjena na Nemačku. Stojadinović, kao i Horti i kralj Karol, bio je svestan opasnosti koja mu preti od fašističkog ${ }^{73}$ pokreta oslonjenog na Nemačku, te je rešio da ,saseče u korenu“ njegovu popularnost. Na to upućuje činjenica da u novinskim člancima nije bilo nikakvog kompromitujućeg materijala niti dokumenata, već su optužbe protiv Zbora počivale samo na opšte dostupnim podacima o TU. Za razliku od hipoteze o nemačkom poreklu ove afere, u izvorima postoje posredni dokazi da je ona inicirana od jugoslovenskih političkih činilaca. ${ }^{74}$

Afera „Tehnička unija“ trajno je naškodila ugledu JNP Zbora, ali se nije temeljno odrazila na jugoslovensko-nemačke odnose, jer su se nemački organi okrenuli saradnji sa režimom. ${ }^{75}$ Tako su službenici APA, koji su inicirali pregovore sa Zborom oko TU još 1936. godine, sarađivali u izbornoj propagandi Milana Stojadinovića dve godine kasnije. ${ }^{76}$ Zbog osetljivosti jugoslovenskog reži-

\footnotetext{
${ }^{71}$ AJ, Zbirka 37, Milan Stojadinovića, 30-217, Miloš Crnjanski - Milanu Stojadinoviću, 31. 12. 1937.

72 Димитрије Љотић, Прича о шећеру илити горка истина (Смедерево: п. и., 1939), 44-45.

${ }^{73}$ Iako u istoriografiji ne postoji konsenzus oko toga da li je JNP Zbor fašistički ili ekstremno desničarski pokret, prema našem mišljenju, u skladu sa teoretskim modelom Rodžera Grifina, Zbor ispunjava „,fašistički minimum“. Roger Griffin, The Nature of Fascism (London: Pinter, 1991).

${ }^{74}$ Arhiv Srbije (AS), Bezbednosno-informativna agencija (BIA), II-69, Zbor Dimitrija Ljotića, str. 10; IAB, BIA, dosije Velibora Jonića, Zapisnik sa saslušanja Velibora Jonića; HDA, Služba državne sigurnosti (SDS), šifra 10, 10, Jugoslavenski narodni pokret „Zbor“; Х. Бев-Мери, $\mu$. d., 41; N. Mühlen, op. cit., 138.

${ }^{75}$ I 1940. godine optužbe protiv Zbora zbog TU nisu jenjavale. Vidi: IAB, 1929, k-3, Letak Studentskog odbora za odbranu zemlje, 13. 4. 1939; Димитрије Љотић, „Уутарњем листу и сличнима што су од пре неки дан почели мислити на државу“, СД8, 260-266; „Техничка унија, Марсел Сркуљ и Збор“, Haw nуm, 28. 1. 1940.

76 Бојан Симић, Пропаганда Милана Стојадиновића (Београд: Институт за новију историју Србије, 2007), 162-163.
} 
ma na bilo kakvo javno iskazivanje naklonosti prema Zboru, Zbor je izostavljen iz posebnog broja časopisa Weltkampf posvećenog fašističkim pokretima u svetu. Nakon što je Ministarstvo inostranih poslova upitano od strane APA za mišljenje o tome da li treba Zboru posvetiti jedan članak, iz Vilhelmštrase stigao je odgovor da iako ima ,jasne sličnosti sa nacizmom“, pokret je u opoziciji prema Stojadinoviću, te se ne preporučuje ,iskazivanje interesa za pokret od organa Rajha“، ${ }^{77}$ U pripremi dana partije 1939. godine Zbor je, zajedno sa Gvozdenom gardom i Strelastim krstovima, uvršten u spisak fašističkih pokreta koji bi mogli prisustvovati. Ministarstvo spoljnih poslova smatralo je da nema prepreka da članovi Zbora budu pozvani, ali ne u svojstvu pokreta i nipošto u uniformama i obeležjima. Predlog da se na istu proslavu pozove Stojadinović odbijen je zbog toga što je on pao sa vlasti i bio u opoziciji prema Cvetkovićevom režimu. Ovaj partijski kongres, ironično nazvan „Dan mira“, otkazan je zbog napada Nemačke na Poljsku i početka rata, te njemu nisu prisustvovali članovi Zbora. ${ }^{78}$ Da svi kontakti između Nemaca i članova Zbora nisu prekinuti posle kraha TU, dokazuje pismo Dimitrija Ljotića knezu Pavlu iz juna 1940. godine. Ljotić navodi da se jedan ,njegov prijatelj“ susreo sa izvesnim Nemcem, Gruberom, koji mu je preneo da Nemci nisu zainteresovani za spasavanje Stojadinovića, jer je on sarađivao sa francuskom službom. Ljotić je ubeđivao kneza Pavla da Nemci neće dozvoliti hrvatski separatizam niti agresivne planove Italije. ${ }^{79}$ Kada je pokret zabranjen oktobra 1940. godine, zvanična novinska agencija DNB donela je izveštaj pun pohvala na račun Zbora, koji je zabranjen od strane masona i filosemita u jugoslovenskoj vladi, apostrofirajući Mihaila Konstantinovića kao tvorca zabrane. ${ }^{80}$ I ideološke brošure čiji su autori bili bliski Zboru, poput Branimira Maleša, bile su praćene od nemačkih organa. ${ }^{81}$

Prepreku za dalju saradnju Zbora i nacističke Nemačke predstavljalo je izbijanje Drugog svetskog rata. Iako je okupacija Čehoslovačke praktično prećutana, a pojedini članovi Zbora su tu državu predstavljali kao ,žrtvu zapadne demokratije i boljševičke Rusije“, 82 Dimitrije Ljotić duboko se protivio izbijanju rata. Taj sukob Ljotić nije smatrao samo ratom između dve zaraćene strane, već apokaliptičnim sukobom i revolucijom, i polugom jevrejskog gospodarenja svetom. ${ }^{83}$ Smatrao je da je spoljnopolitički imperativ Jugoslavije da po svaku

\footnotetext{
${ }^{77}$ PA AA, RZ 211, R103374, Spoljnopolitička služba NSDAP-a - Ministarstvu spoljnih poslova, 3. 10. 1938; Ministarstvo spoljnih poslova - Spoljnopolitičkoj službi NSDAP-a, 12. 10. 1938.

${ }^{78}$ PA AA, RZ 214, R 99152, Lista pozvanih za partijski kongres 1939; PA AA, RZ 214, R 99153, Zabeleška o učestvovanju fašističkih grupa na danu partije 1939, 19. 7. 1939; Stav Ministarstva spoljnih poslova o učestvovanju fašističkih grupa na danu partije 1939, 20. 7. 1939.

${ }^{79}$ AJ, Mikrofilmovana zbirka kneza Pavla, 797, rolna 15, fotografije 420-422, pismo Dimitrija Ljotića - knezu Pavlu, 22. 6. 1940.

${ }^{80}$ BArch, Deutsches Auslandswissenschaftliches Institut (R 4902)/4283, DNB Bilten, 4. 11. 1940.

${ }^{81}$ Tako je odeljenje SS-a „Anenserbe“ razmišljalo o prevođenju brošure „Rasna pripadnost Jugoslavije“. Vidi: BArch, Forschungs - und Lehrgemeinschaft „Das Ahnenerbe“ (NS 21)/397, Pismo SS potporučnika Bema - SS majoru Grajteu, 30. 1. 1941; Pismo SS majora Grajtea - SS potporučniku Bemu, 9. 4. 1941.

${ }^{82}$ IAB, 1929, k-3, Letak Građani, JNP Zbor Sušak.

83 Димитрије Љотић, „Размишљања о рату“, СД2, 112-117.
} 
cenu ostane van tog rata, jer će joj on označiti kraj. Stoga je dosledno zagovarao jugoslovensku neutralnost. Ljotić piše: „Novi rat ima sa sobom da donese nove teškoće a možda i definitivni slom čitave hrišćanske kulture i civilizacije." ${ }^{84}$ Kada je rat ipak počeo, u njemu je preovladala svest o nemačkoj krivici. Vođen svojom od „Promisli“" podarenom misijom da sruši boljševizam, ${ }^{85}$ Adolf Hitler je izazvao rat i time zapravo pomogao boljševizmu i jevrejstvu da trijumfuju. „On [rat - R. L.] je zločin prema Evropi i čovečanstvu. Zločin je učinio Hitler što ga je neposredno izazvao. ${ }^{66}$ On nije imao nikakvih iluzija da je taj rat Nemačkoj nametnut i javno je to u svom Biltenu pisao, smatrajući da ona,,vidi zlo očima“" i da stoga želi rat. ${ }^{87}$ Ljotić je na više mesta zaključio da su zbog toga što su izazvali rat Adolf Hitler i Benito Musolini zapravo „nesvesni jevrejski agenti““ ${ }^{88}$ Zaslepljen svojim antisemitizmom, smatrao je Ljotić, Hitler ne shvata da svojim ratom pomaže upravo onima protiv kojih se bori. Važno je istaknuti da Dimitrije Ljotić ovim nije želeo da insinuira da je Adolf Hitler deo ,jevrejske zavere", niti da on svesno sprovodi jevrejske naume u delo, već da je to plod njegove kratkovidosti. Ljotić je zaključio da postoje dva Hitlera, jedan ,neodlučan, nevešt, apatičan, bojažljiv“, a drugi „neljudska i reklo bi se, nezemaljska, satanska snaga“. ${ }^{89}$ Upravo je ta ,satanska snaga“ pokrenula rat, i ta ,satanska snaga" dovodi do sumraka hrišćanske Evrope. Nemačka je samim tim postala opasna: „Istina je da je Nemačka svojim nehrišćanskim, brutalnim postupcima, opasnost za male i srednje države u Evropi. “90 Iz protesta, članovi Zbora Olćan i Mojić istupili su iz Nemačko-jugoslovenskog društva. ${ }^{91}$

Kritika agresivne ratne politike Nemačke nije širena na samu ideologiju nacionalsocijalizma, koja više nije kritikovana. ${ }^{92}$ Zboraši su, međutim, bili rešeni da u slučaju rata brane zemlju od Nemačke. Janko Vujić je u pismu ministru vojske predlagao pravljenje spiskova Nemaca koji u slučaju rata treba da budu uzeti kao taoci, ${ }^{93}$ dok je Ljotić iz skrovišta slao uputstva članovima da se odazovu mobilizaciji. ${ }^{94}$ Ljotićeva kritika nije prošla nezapaženo, ali nije do kraja pokvarila odnose sa Nemačkom. Već citirani dokumenti pokazuju da su nemač-

\footnotetext{
${ }^{84}$ Исто, 114.

85 Димитрије Љотић, „Без наслова“, СД7, 6.

${ }^{86}$ Димитрије Љотић, „Једно схватање неутралности“, СД9, 41.

${ }^{87}$ Димитрије Љотић, „Слаби изгледи за мир“, СД8, 195. Pojedini zboraši bili su i oštriji. Tako je Živko Brković na jednom skupu nazvao Hitlera i Musolinija „zakletim“ i ,večnim“ neprijateljima Jugoslavije. HDA, 1353, Inv. br. 3969, Komanda žandarmerije - Banskoj vlasti Banovine Hrvatske, Odjelu za državnu zaštitu, 12. 3. 1940.

${ }^{88}$ Димитрије Љотић, „Спољни преглед“, $C Д 7,83$; Димитрије Љотић, „Закључак“, $C Д 7,212$; Димитрије Љотић, „Једно цинично јеврејско признање“, $C Д 7,252$; Димитрије Љотић, „Погрешан рачун г. Хитлера“, СД8, 23; Димитрије Љотић, „Драма савременог човечанства“, СД12, 57-125.

89 Димитрије Љотић, „Отсудни (sic) час““, СД9, 111.

90 Димитрије Љотић, „Нове опасности“, СД8, 244.

${ }^{91}$ IAB, BDS, Dosije Mihaila Olćana (O-39), Zabeleška, 24. 9. 1942.

92 Vidi: Роко Калеб, „Тајна немачког успеха“, Haw nym, 21. 6. 1940.

${ }^{93}$ IAB, 115, Pismo Janka Vujića - ministru vojnom, 11. 5. 1940.

${ }^{94}$ IAB, 1929, k-7, Dragi druže!
} 
ki organi do izbijanja rata imali pozitivno mišljenje o pokretu. Kritika Nemačke zbog otpočinjanja rata dovela je, međutim, do uvrštavanja Zbora u kartoteku neprijateljskih pokreta, zbog ,velikojugoslovenskog stava““95 Aprilski rat i okupacija Srbije zameniće obostrano nepoverenje svešću da su potrebni jedni drugima. Zboru i Ljotiću je oslonac na okupatora bio potreban zbog dolaska na vlast u državi, dok su Nemcima bili potrebni saradnici u zemlji u koje su mogli da imaju (iako ograničeno) poverenje. U celini posmatrano, prema našem istraživanju ne postoji nikakav dokaz za tezu o JNP Zboru kao agenturi nemačke obaveštajne službe tokom međuratnog perioda. Tehnička unija je zamišljena prevashodno kao privredni poduhvat koji je trebalo da nadopunjuje postojeće međudržavne sporazume, a čija je posledica (ali ne i uzrok) trebalo da bude jačanje JNP Zbora. Iako u međuratnom periodu ne postoje podaci da je Zbor bio u sklopu nemačke obaveštajne mreže, tokom okupacije na to pitanje mnogo je teže dati odgovor. ${ }^{96}$ Naime, za izvestan broj visokih funkcionera pokreta postoje konkretni podaci da su bili u službi nemačkih organa, dok se za samog Dimitrija Ljotića to ne može kategorički tvrditi, iako nije neosnovano pretpostaviti da je bio upućen u kontakte svojih najbližih saradnika (poput sekretara Boška Kostića) sa Glavnom upravom sigurnosti Rajha. ${ }^{97}$

\section{REFERENCE}

- Avramovski, Živko. Britanci o Kraljevini Jugoslaviji, knj. 2. Beograd/Zagreb: Arhiv Jugoslavije/Globus, 1986.

- Božović Branislav, i Mladen Stefanović. Milan Aćimović, Dragi Jovanović, Dimitrije Ljotić. Zagreb: CIP, 1985.

- Bev-Meri, Hubert. K najvećoj Nemačkoj. Zagreb: b. i., b. g.

- Biber, Dušan. Nacizem in Nemci v Jugoslaviji. Ljubljana: Cankarjeva založba, 1966.

- Bojić, Mirko. Jugoslavenski narodni pokret ZBOR. Beograd: Narodna knjiga, 1999.

- Ćuruvija, Slavko. Ibeovac ja, Vlado Dapčević. Beograd: Filip Višnjić, 1990.

- Gligorijević, Branislav. „Politički pokreti i grupe s nacionalsocijalističkom ideologijom i njihova fuzija u Ljotićevom 'Zboru'". Istorijski glasnik, br. 4, (1965), 35-83.

- Griffin, Roger. The Nature of Fascism. London: Pinter, 1991.

- Hobsbaum, Erih. Doba ekstrema: istorija Kratkog dvadesetog veka. Beograd: Dereta, 2004.

- Hoptner, Jacob. Jugoslavija u krizi 1934-1941. Rijeka: Otokar Keršovani, 1972.

- Ivanović, Predrag. Ko su ljotićevci?. Kragujevac: Pogledi, 2014.

${ }^{95}$ Vidi prvu seriju kartoteka koju je sastavilo odeljenje VI (Spoljna služba bezbednosti) RSHA. BArch, Reichssicherheitshauptamt (R58)/ 1144.

${ }^{96}$ O kolaboraciji JNP Zbora tokom okupacije vidi: Branislav Božović i Mladen Stefanović, Milan Aćimović, Dragi Jovanović, Dimitrije Ljotić (Zagreb: CIP, 1985); А. Стојановић, н. д.

${ }^{97}$ IAB, BIA, dosije Ludviga Tajhmana; HDA, SDS, šifra 11.5, 1, Milan Banić, Ljotićev „Zbor“ i „zboraši“, 16. 12. 1957. 
- Janjetović, Zoran. Deca careva, pastorčad kraljeva. Nacionalne manjine u Jugoslaviji. Beograd: Institut za noviju istoriju Srbije, 2005.

- Kačavenda, Petar. Nemci u Jugoslaviji 1918-1945. Beograd: Institut za savremenu istoriju, 1991.

- Koljanin, Milan. Jevreji i antisemitizam u Kraljevini Jugoslaviji 1918-1941. Beograd: Institut za savremenu istoriju, 2008.

- Kovačev, Vujica. Na zajedničkom frontu revolucije. Beograd: Institut za savremenu istoriju, 1987.

- Ljotić, Dimitrije. Priča o šećeru iliti gorka istina. Smederevo: p. i., 1939.

- Ljotić, Dimitrije. Sabrana dela 1-12. Beograd: Zadruga, 2001.

- Milanović, Života. Koga su najmili da ih brani?. b. m: b. i., 1938.

- Milenković, Toma. „Nekoliko dokumenata o delatnosti Jugoslovenskih internacionalista u Mađarskoj Sovjetskoj Republici“‘. Prilozi za istoriju socijalizma, br. 6, (1969), 331-355.

- Milenković, Toma. „Vladimir Ćopić u jugoslovenskom radničkom pokretu“. U: Vladimir Ćopić: život i djelo. Rijeka: CHRP, 1978, 105-123.

- Mühlen, Norbert. Der Zauberer. Leben und Anleihen des dr. Hjalmar Horace Greeley Schacht. Zürrich: Europa Verlag, 1938.

- Nemačka obaveštajna služba, knj. II-IV. Beograd: UDB, III odeljenje, 1955-1959.

- Nikolić, Kosta. Boljševizacija KPJ 1919-1929. Beograd: Institut za savremenu istoriju, 1994.

- Odić Slavko, i Slavko Komarica. Noć i magla: Gestapo u Jugoslaviji. Zagreb: Centar za informacije i publicitet, 1977.

- Parežanin, Ratko. Drugi svetski rat i Dimitrije V. Ljotić. Beograd: privatno izdanje, 2001.

- Paunović, Svetomir. Sećanja svedoka jednog vremena. Beograd: S. R. Paunović, 2004.

- Propadović, Milutin. D. V. Ljotić i Komunistička partija Jugoslavije. Northampton: Iskra, 1990.

- Simić, Bojan. Propaganda Milana Stojadinovića. Beograd: Institut za noviju istoriju Srbije, 2007.

- Stefanović, Mladen. Zbor Dimitrija Ljotića. Beograd: Narodna knjiga, 1984.

- Stipetić, Zorica. Argumenti za revoluciju: August Cesarec. Zagreb: CDC, 1982.

- Traverso, Enzo. Fire and Blood: The European Civil War. London: Verso, 2016.

- Zečević, Miodrag. Dokumenta sa suđenja ravnogorskom pokretu, knj. 1. Beograd: SUBNOR, 2001. 
MA RASTKO LOMPAR, Junior Research Assistant

Institute for Balkan Studies SASA

Belgrade, Republic of Serbia

rastko.lompar@bi.sanu.ac.rs

\section{THE “TECHNISCHE UNION” AFFAIR AND CONTACTS BETWEEN THE YNM ZBOR AND NAZI GERMANY 1935-1941}

\section{Summary}

Since its creation in 1935, the Yugoslav National Movement Zbor had a special connection with Nazi Germany. Dimitrije Ljotić quickly overcame his initial skepticism toward National Socialism and the movement adopted an unmistakably pro-Nazi stance. This shift did not go unnoticed by the German side, and after April 1936 the YNM Zbor maintained contacts with various German official and unofficial representatives. As a result, in late 1936 an ambitious plan was hatched, which foresaw the establishment of the so called "Technische Union" society. The TU was supposed to be a joint Yugoslav-German venture which would increase economic cooperation between the two countries and simultaneously strengthen Zbor's position in Yugoslavia. However, Yugoslav Prime Minister Milan Stojadinović did not look favorably upon the possible strengthening of Zbor. Therefore, starting in early 1937, his allies started attacking Zbor openly, both in the parliament and in the press, claiming that the movement was illegally financed from Germany and therefore was in fact a German "fifth column" in Yugoslavia. These accusations were quickly picked up by the foreign press and the scandal started damaging Germany's foreign political position. Therefore, both the Germans and Dimitrije Ljotić's followers started distancing themselves from the TU, which soon collapsed. This scandal left a lasting mark on the ties between Zbor and the German officials. When Germany plunged the world into war in 1939, Ljotić started adopting a more critical attitude toward National Socialism which also strained their relations. However, the contacts were never broken off entirely and the Germans continued monitoring the fate of the movement closely, especially during the events that led to the outlawing of Zbor in November of 1940.

KEYWORDS: YNM Zbor, Dimitrije Ljotić, National Socialist Germany, German Intelligence Service, Technische Union 